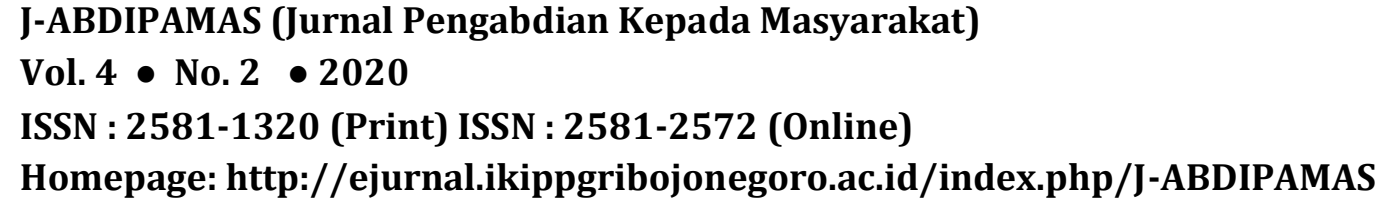

ISSN : 2581-1320 (Print) ISSN : 2581-2572 (Online)

Homepage: http://ejurnal.ikippgribojonegoro.ac.id/index.php/J-ABDIPAMAS

\title{
PENGUATAN STRATEGI PEMASARAN DENGAN KEMASAN KEKINIAN PADA PROPOSAL RENCANA BISNIS UMKM DESA KEBONTUNGGUL KABUPATEN MOJOKERTO
}

\author{
Cesya Rizkika Parahiyanti ${ }^{1}$, Yana Respati Dewi ${ }^{2}$, Arum Prasasti ${ }^{3}$,Ita Prihatining \\ Wilujeng ${ }^{4}$ \\ ${ }^{1}$ Universitas Negeri Malang. Email: cesya.rizkika.fe@um.ac.id \\ 2 Universitas Negeri Malang. Email: yana.respati.fe@um.ac.id \\ ${ }^{3}$ Universitas Negeri Malang. Email: arum.prasasti.fe@um.ac.id \\ 4 Universitas Negeri Malang Email: ita.prihatining.fe@um.ac.id
}

\begin{abstract}
Community empowerment in the era of globalization is facing big challenges. Desa Kebontunggul also faces the same challenge. Desa Kebontunggul is one of the villages located in Gondang, Kabupaten Mojokerto, which becomes a concern for village community empowerment office in Mojokerto. This village has a lot of potential to be developed because its strategic geographical location on the slopes of Mount Anjasmoro. Desa Kebontunggul has some superior products to be developed such as family medicinal plants (toga), organic plants, mushrooms, tortillas, and eggs. Unfortunately, the popularity of those products could not be competed to its natural tourism which is Mbencirang Valley. This community service activity aims to provide training and assistance in making business plan, especially strengthening the marketing plan for micro, small and medium enterprises (MSMEs) in Kebontunggul. Through this training and mentoring, superior products of MSMEs in the village are expected having a good marketing plan, thus, they can increase the added value of the products.
\end{abstract}

Keywords: Desa Kebontunggul, business plan, added value, marketing strategy

\begin{abstract}
ABSTRAK
Pemberdayaan masyarakat di era globalisasi sedang menghadapi tantangan yang besar. Kondisi ini juga tidak terkecuali untuk masyarat di desa. Desa Kebontunggul merupakan salah satu desa yang terletak di Kecamatan Gondang, Kabupaten Mojokerto yang menjadi perhatian bagi Dinas Pemberdayaan Masyarakat dan Desa di Kabupaten Mojokerto. Desa ini memiliki banyak potensi untuk dikembangkan karena letak geografisnya terbilang strategis di lereng Gunung Anjasmoro. Dari segi produk yang bisa dikembangkan, Desa Kebontunggul memiliki potensi produk unggulan diantaranya toga (tanaman obat keluarga), tanaman organik, jamur, tortilla, dan telur. Namun sayang, kepopuleran produk-produk tersebut belum bisa sebanding dengan wisata alam di Kebontunggul yaitu Wisata Lembah Mbencirang. Pengabdian masyarakat ini dilakukan untuk memberikan pelatihan serta pendampingan pembuatan proposal rencana bisnis khususnya penguatan pada rencana pemasaran kepada para pelaku usaha mikro kecil menengah (UMKM) di desa Kebontunggul. Dengan adanya pelatihan dan pendampingan ini, diharapkan masyarakat desa Kebontunggul, khususnya warga yang memiliki usaha di produk unggulan desa, akan memiliki rencana pemasaran bisnis yang baik sehingga dapat menambah nilai tambah dari produk yang dihasilkan.
\end{abstract}

Kata Kunci: Desa Kebontunggul, rencana bisnis, nilai tambah, strategi pemasaran 


\section{PENDAHULUAN}

Pemberdayaan masyarakat, secara lugas dapat diartikan sebagai suatu proses yang membangun manusia atau masyarakat melalui pengembangan kemampuan masyarakat, perubahan perilaku masyarakat, dan pengorganisasian masyarakat (Yasin, 2019). Kemampuan masyarakat yang dapat dikembangkan mencakup banyak hal seperti kemampuan untuk berusaha, kemampuan dalam pencarian informasi, kemampuan mengelola kegiatan, kemampuan dalam pertanian, dan kemampuan lainnya sesuai dengan kebutuhan atau permasalahan yang sedang dihadapi oleh masyarakat. Yang dikembangkan dari masyarakat yaitu potensi atau kemampuannya dan sikap hidupnya. Kemampuan masyarakat meliputi antara lain kemampuan untuk bertani, beternak, melakukan wirausaha, dan masih banyak lagi. Pengembangan kemampuan dan keterampilan ini dapat dilakukan dengan berbagai cara diantaranya dengan program pelatihan dan pendampingan.

Ada beberapa prinsip dasar pemberdayaan guna mewujudkan masyarakat yang berdaya dan mandiri. Prinsip dasar ini meliputi penyadaran, pelatihan, pengorganisasian, pengembangan kekuatan, dan membangun dinamika. Pelatihan sebagai salah satu prinsip dasar terkait dengan pendidikan yang bukan hanya belajar membaca, menulis, berhitung, tetapi juga meningkatkan keterampilan-keterampilan bertani, kerumahtanggaan, serta cara-cara seperti bagaimana memakai jasa bank, bagaimana membuka rekening, dan memperoleh pinjaman. Melalui pelatihan dan dikuatkan dengan adanya pendampingan, kesadaran masyarakat akan terus berkembang.

Salah satu jenis pelatihan yang dapat diberikan guna melakukan pemberdayaan masyarakat desa adalah mengenai rencana bisnis. Rencana bisnis (business plan) merupakan salah satu dokumen penting bagi seorang wirausaha ketika akan meluncurkan bisnisnya. Proposal rencana bisnis yang baik adalah proposal yang komprehensif, ditulis, serta diatur dengan baik sehingga dokumen tersebut bisa menjadi pegangan bagi pengusaha dan dapat menjadi instrumen dalam mendapatkan modal dan pendanaan. Proposal rencana bisnis yang komprehensif seharusnya dapat dibaca oleh pegawai, investor, pemberi sewa, pemasok, pelanggan dan juga konsultan. Salah satu komponen penting di dalam rencana bisnis adalah rencana pemasaran. Pada rencana pemasaran, para pemilik usaha diharapkan memberikan penjelasan mengenai nama merek, produk yang dijual, sampai dengan strategi-strategi pemasaran apa saja yang digunakan untuk memasarkan produk kepada para pelanggan. 
Desa Kebontunggul merupakan salah satu desa yang menjadi perhatian bagi Dinas Pemberdayaan Masyarakat dan Desa di Kabupaten Mojokerto. Desa ini memiliki banyak potensi untuk dikembangkan karena letak geografisnya terbilang strategis di lereng Gunung Anjasmoro. Dari segi produk yang bisa dikembangkan, Desa Kebontunggul memiliki potensi produk unggulan diantaranya toga (tanaman obat keluarga), jamur, telur, jamu, dan juga olahan jagung berupa tortilla. Namun sayang, kepopuleran produkproduk tersebut belum bisa sebanding dengan wisata alam di Kebontunggul yaitu Wisata Lembah Mbencirang. Sesuai hasil observasi awal, Kepala Desa Kebontunggul, Siandi, mengatakan bahwa kualitas produk yang dihasilkan oleh para pelaku usaha di desa Kebontunggul bisa bersaing dengan produk-produk di luaran sana. Namun, banyak pelaku usaha mendapatkan kesulitan dalam menentukan strategi pemasaran yang digunakan terutama pada strategi penggunaan kemasan produk. Bahkan, banyak pelaku usaha yang belum memiliki merek pada produk mereka. Sebagian besar pelaku usaha menjual produk-produknya dengan menggunakan tas plastik tanpa adanya nilai tambah sedikitpun sehingga nilai jual dari produk mereka juga tidak begitu tinggi. Padahal, rencana pemasaran ini cukup memegang peranan penting dalam pembuatan proposal rencana bisnis yang nantinya bisa digunakan dalam pencarian modal usaha. Terkait akan permasalahan tersebut, tim pengabdian masyarakat Fakultas Ekonomi, Universitas Negeri Malang (FE UM), mengadakan pelatihan dan pendampingan pembuatan proposal rencana bisnis, khususnya penguatan strategi pemasaran dengan kemasan kekinian. Kegiatan ini diharapkan dapat menambah nilai produk dari para UMKM di desa Kebontunggul sebagai dasar dalam meningkatkan harga jual serta sebagai langkah awal dalam pembuatan proposal rencana bisnis yang komprehensif guna dapat digunakan dalam pencairan modal usaha.

\section{METODE PELAKSANAAN}

Kegiatan pengabdian masyarakat yang dilakukan oleh tim berfokus pada pelatihan serta penyusunan proposal rencana bisnis khususnya mengenai strategi pemasaran melalui kemasan kekinian sehingga nantinya para pengusaha di desa Kebontunggul dapat menambah nilai produk serta memiliki proposal rencana bisnis yang baik dan komprehensif. Proposal ini nantinya dapat digunakan sebagai pegangan bagi para pembisnis dalam mencari modal dan pendanaan ke lembaga keuangan seperti bank, koperasi, serta investor. 
Target dari kegiatan pengabdian masyarakat ini adalah warga desa Kebontunggul yang sudah memiliki bisnis, khususnya bisnis produk unggulan desa serta warga yang berencana akan mendirikan sebuah bisnis. Solusi yang diberikan oleh tim pengabdian masyarakat adalah pelatihan dan penyusunan proposal rencana bisnis. Menurut Hisrich, et al (2017), proposal rencana bisnis yang baik dan komprehensif sehingga layak untuk digunakan sebagai dasar dokumen pencarian pendanaan bagi pengusaha setidaknya berisi 11 komponen. 11 komponen tersebut terdapat pada Tabel 1. Berdasarkan informasi serta outline rencana bisnis yang disebutkan sebelumnya, fokus target dari kegiatan ini adalah pelatihan serta pendampingan penyusunan proposal rencana bisnis khususnya penguatan pada strategi pemasaran melalui kemasan kekinian.

Tabel 1. Outline Rencana Bisnis

\begin{tabular}{|l|l|l|}
\hline No & \multicolumn{1}{|c|}{ Nama Komponen } & \multicolumn{1}{c|}{ Ringkasan Isi } \\
\hline 1 & Halaman Pengantar & $\begin{array}{l}\text { Identitas bisnis seperti nama produk, anggota organisasi, } \\
\text { total biaya pendanaan yang dibutuhkan }\end{array}$ \\
\hline 2 & Ringkasan Eksekutif & Ringkasan keseluruhan isi rencana bisnis \\
\hline 3 & Analisis Industri & $\begin{array}{l}\text { Gambaran lingkungan eksternal dan analisis pesaing yang } \\
\text { terkait dengan bisnis }\end{array}$ \\
\hline 4 & Deskripsi Usaha & Visi dan misi usaha, detail produk, latar belakang pengusaha \\
\hline 5 & Rencana Produksi & $\begin{array}{l}\text { Proses manufaktur, rencana bangunan usaha, daftar mesin } \\
\text { dan peralatan yang dibutuhkan }\end{array}$ \\
\hline 6 & Rencana Operasi & Pembuatan produk atau proses jasa, alur pemesanan produk \\
\hline 7 & Rencana Pemasaran & $\begin{array}{l}\text { Produk, promosi, pilihan tempat, penetapan harga, ramalan } \\
\text { produk }\end{array}$ \\
\hline 8 & Rencana Organisasi & $\begin{array}{l}\text { Formulir kepemilikan usaha, identifikasi rekanan, peran dan } \\
\text { tanggung jawab tiap-tiap anggota }\end{array}$ \\
\hline 9 & Rencana Keuangan & $\begin{array}{l}\text { Proyeksi arus kas, analisis balik modal, sumber dan aplikasi } \\
\text { pendanaan }\end{array}$ \\
\hline 10 & Penilaian Risiko & $\begin{array}{l}\text { Evaluasi kelemahan usaha, menilai peluang dan ancaman } \\
\text { teknologi, rencana masa depan }\end{array}$ \\
\hline 11 & Lampiran & $\begin{array}{l}\text { Data riset pasar, daftar harga dari pemasok, dan data lain } \\
\text { yang mendukung tiap-tiap komponen }\end{array}$ \\
\hline
\end{tabular}

Source: Hisrich, et al., 2017

Metode pelaksanaan kegiatan pengabdian masyarakat pada desa Kebontunggul dibagi menjadi 3 tahapan yaitu:

\section{Persiapan}

Tim pengabdian FE UM akan melakukan kerja sama dengan pihak-pihak yang terlibat yaitu pengurus desa Kebontunggul, Dinas Pemberdayaan Masyarakat dan Desa (PMD) Kabupaten Mojokerto, serta masyarakat desa yang ditunjuk sebagai peserta pelatihan. Target peserta pelatihan dan pendampingan sebanyak 20 peserta. Adapun lebih lanjut, tahap persiapan meliputi kegiatan: 
1. Penyusunan proposal tim pengabdian

2. Melakukan komunikasi dengan pengurus desa Kebontunggul dan Dinas PMD Kabupaten Mojokerto

3. Pengurus desa mengusulkan 20 nama peserta pelatihan

4. Tim pengabdian melakukan observasi awal dengan menganalisa kondisi bisnis atau usaha yang berada di desa Kebontunggul

5. Tim pengabdian melakukan analisis SWOT kondisi bisnis yang berhubungan dengan penyusunan proposal rencana bisnis, khususnya data dan informasi yang diberikan oleh 20 calon peserta pelatihan

\section{Pelaksanaan}

Pelaksanaan proses pelatihan dan pendampingan dilakukan dua kali. Tahap awal adalah pemaparan 11 komponen pembentuk proposal rencana bisnis komprehensif kepada peserta. Selain itu, peserta juga diberikan informasi mengenai tren serta cara-cara pencarian modal dan pendanaan bagi usaha kecil. Setelah pemaparan 11 komponen, para peserta diberikan penguatan terkait rencana pemasaran khususnya pada pembuatan kemasan kekinian dengan menggunakan media yang mudah dan gratis sehingga tidak akan menyulitkan peserta untuk melakukan hal serupa.

\section{HASIL DAN PEMBAHASAN}

\section{Tahap Persiapan}

Pada tahap persiapan, tim pengabdian masyarakat FE UM melakukan observasi melalui kegiatan diskusi dengan perangkat desa yaitu Kepala Desa Kebontunggul, Bapak Siandi, Sekretaris Dinas Pemberdayaan Masyarakat Desa (PMD) Kabupaten Mojokerto, Bapak Suhartono serta beberapa personil dari Badan Usaha Milik Desa (BUMDES) yaitu Ibu Yuli, Norma, dan Andi. Dari kegiatan diskusi ini, tim menyampaikan pesan akan melakukan kegiatan pelatihan pemyusunan proposal bisnis. Namun, kepala desa mengatakan agar pelatihan lebih dikuatkan pada rencana pemasaran khususnya mengenai kemasan karena banyak pelaku usaha di Desa Kebontunggul yang belum memiliki nama merek, logo, serta kemasan penjualan yang layak. Pelatihan mengenai strategi pemasaran pada produk ini nantinya diharapkan dapat meningkatkan nilai jual dari produk yang dihasilkan oleh warga desa. Siandi juga menambahkan bahwa BUMDES berencana akan mendirikan BUMDES mart berlokasi di wisata Lembah Mbencirang. Toko 
ritel tersebut rencananya akan menampung produk-produk hasil olahan masyarakat desa Kebontunggul sehingga pengunjung wisata dapat menjadikan produk tersebut sebagai oleh-oleh khas Desa Kebontunggul.

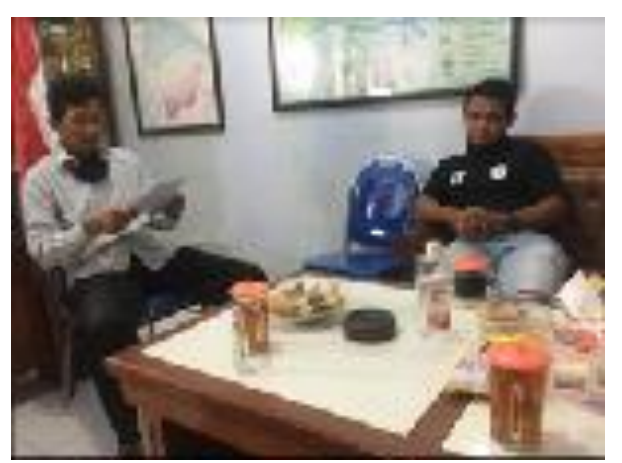

Gambar 1. Kegiatan Observasi dan Diskusi Awal dengan Perangkat Desa Sumber: Dokumentasi Pribadi, 2020

Rencana pemasaran merupakan salah satu komponen penting di dalam proposal rencana bisnis (Hisrich, et al., 2017). Di dalam rencana pemasaran, pelaku usaha harus mampu memaparkan mengenai detail produk, pilihan lokasi dan tempat penjualan, penetapan harga, serta menentukan pelanggan melalui analisis segmentasi, target, dan posisi. Logo serta kemasan juga memegang fungsi penting tidak hanya pada rencana pemasaran saja, tetapi juga sudah ditampilkan sebagai halaman muka proposal rencana bisnis yaitu pada halaman pengantar (Tabel 1). Sesuai dengan yang dikemukakan oleh Kepala Desa Kebontunggul, desain kemasan juga memegang peranan penting pada sebuah usaha Marina pada artikel yang ditulis oleh Lin (2017) menyebutkan beberapa fungsi kemasan bagi sebuah produk diantaranya:

1. Melindungi dan mengamankan sebuah produk

2. Membedakan dan mengidentifikasi suatu produk dari para pesaingnya

3. Membuat produk lebih menarik dan eye-catching

4. Nyaman untuk dibawa

5. Memuat segala informasi produk kepada pelanggan (seperti informasi halal, komposisi, tanggal kadaluarsa, info sosial media dan lain sebagainya)

Secara lebih rinci, sebuah desain dan kemasan suatu produk merupakan kesan pertama suatu produk yang ingin ditunjukkan oleh penjual kepada konsumen. Bahkan sebuah hasil riset menunjukkan bahwa 52\% konsumen mengatakan bahwa mereka rela membayar sedikit lebih mahal untuk produk-produk dengan kemasan yang mereka sukai. 
30\% laporan bisnis mengatakan bahwa pendapatan usaha mereka meningkat Ketika pembisnis melakukan improvisasi dan perbaikan pada kemasan mereka. Beberapa produk yang dijual oleh masyarakat desa di Kebontunggul belum memiliki kemasan bahkan nama merek serta logo. Padahal salah satu produk yang dihasilkan adalah telur dan jagung. Pembeli terkadang hanya mendapatkan tas plastik biasa Ketika membeli telur di peternak telur di sana. Padahal, kemasan memegang peranan yang sangat penting di sini terutama untuk melindungi produk yang rentan rusak seperti telur. Dari diskusi serta kegiatan observasi ini, tim melakukan analisis SWOT terhadap UMKM yang ada di Desa Kebontunggul sebagai berikut:

1. Strength (kekuatan): produk berkualitas tinggi

2. Weakness (kelemahan): banyak produk belum memiliki kemasan serta desain logo yang layak

3. Opportunities (peluang): desa berada pada letak geografis yang strategik, adanya inisiasi dan rencana pembangunan BUMDES mart sebagai wadah penjualan produkproduk hasil serta buatan masyarakay desa Kebontunggul

4. Threat (ancaman): kalah bersaing dengan para kompetitor yang mengancam harga jual produk-produk khususnya produk komoditas

Pada analisis SWOT, tim pengabdian memutuskan untuk memberikan solusi terhadap kekuatan dan kelemahan (SW) yang ada pada UMKM di Kebontunggul yaitu mengangkat produk berkualitas dengan logo serta desain kemasan yang menarik serta kekinian guna menambah nilai jual serta daya tarik dari produk itu sendiri. Namun, pelatihan ini masih tetap memberikan pemaparan mengenai pentingnya proposal rencana bisnis serta penjelasan setiap komponennya. Hanya saja, pelatihan lebih memprioritaskan pada kegiatan penguatan pemasaran khususnya cara-cara membuat logo serta kemasan kekinian dengan murah dan mudah menggunakan media internet. Pada tahap ini, pihak BUMDES membantu tim dalam menyiapkan peserta sebanyak 20 orang.

\section{Tahap Pelaksanaan}

Pada tahap pelaksanaan, BUMDES mengirimkan data sebanyak 20 orang sebagai peserta pelatihan. Para peserta merupakan pelaku UMKM dengan berbagai macam produk. Tabel 2 menunjukkan sebaran peserta berdasarkan jenis produk yang diolah atau dihasilkan 
Tabel 2. Data Peserta Berdasarkan Jenis Produk

\begin{tabular}{|l|l|}
\hline \multicolumn{1}{|c|}{ Jenis Produk/Olahan } & \multicolumn{1}{c|}{ Jumlah Peserta } \\
\hline Jamu & 3 \\
\hline Jamur & 2 \\
\hline Katering & 1 \\
\hline Kerajinan & 1 \\
\hline Hasil tani (tomat, cabai) & 1 \\
\hline Sablon & 1 \\
\hline Telur & 5 \\
\hline Olahan Jagung (tortilla) & 3 \\
\hline Pihak BUMDES & 3 \\
\hline Total Peserta & $\mathbf{2 0}$ \\
\hline
\end{tabular}

Sumber: Data Diolah, 2020

Pelatihan dilaksanakan di Balai Desa Kebontunggul, Kecamatan Gondang, Kabupaten Mojokerto. Kegiatan pengabdian tetap menerapkan protokol Kesehatan sesuai dengan peraturan pemerintah dalam mengurangi jumlah penyebaran virus covid19. Penerapan protokol Kesehatan ini dilakukan dengan pembagian masker sebagai salah satu seminar kit yang didapat oleh peserta pelatihan, menyediakan hand sanitizer, serta mengatur tata letak tempat duduk peserta dengan jarak yang sesuai dengan standar keamanan.

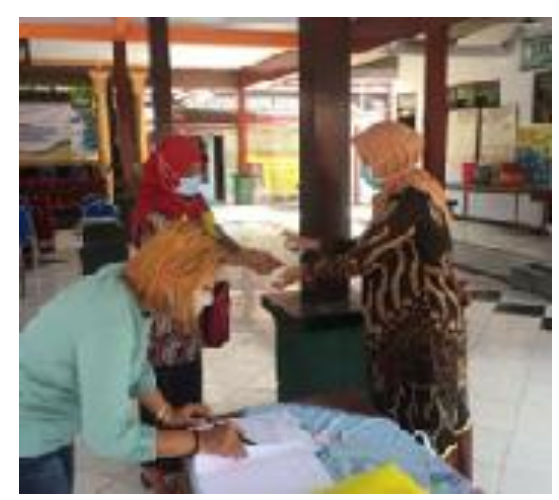

Gambar 2. Penerapan Protokol Kesehatan Pencegahan Virus Covid-19

Sumber: Dokumentasi Pribadi, 2020

Acara dibuka dengan sambutan Kepala Desa Kebontunggul, Siandi, SH., MM. Siandi mengatakan dengan adanya pelatihan ini, ia berharap para pelaku usaha di Desa Kebontunggul dapat meningkatkan kualitas produk mereka khususnya dari segi 
pemasaran. Ia juga menambahkan bahwa sudah saatnya produk-produk unggulan dari Desa Kebontunggul bisa dijajarkan kepopulerannya dengan wisata yang dimiliki oleh desa yaitu Lembah Mbencirang. Kemudian, secara resmi, acara dibuka oleh Sekretaris Dinas Pemberdayaan Masyarakat Desa Kabupaten Mojokerto, Suhartono, SH., M.Si. Suhartono juga berpesan agar pelatihan ini dapat digunakan dalam rangka peningkatan harga jual produk dari UMKM di desa Kebontunggul.

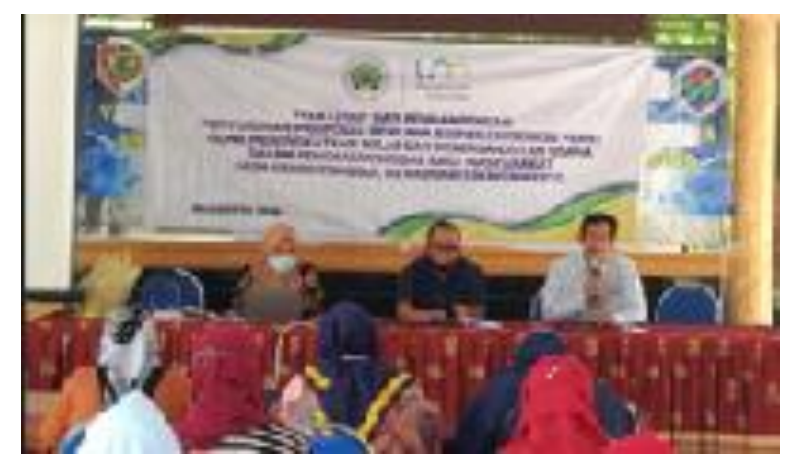

Gambar 3. Acara Pembukaan Kegiatan Pelatihan oleh Kepala Desa dan Dinas PMD Sumber: Dokumentasi Pribadi, 2020

Setelah acara pembukaan, tim pengabdian membuka pemaparan dengan menjelaskan perbedaan antara penjualan dan pemasaran. Para peserta ternyata masih belum paham jika penjualan dan pemasaran adalah dua hal serupa namun berbeda. Penjualan merupakan aktivitas yang lebih menekankan ke ketersediaan produk kepada pelanggan. Sementara, pemasaran lebih menitik beratkan pada peran merek dari suatu produk sehingga produk tersebut menjadi berbeda dari para pesaingnya serta serangkaian aktivitas lainnya yang mendukung sebuah merek agar berhasil memenangkan pikiran serta pilihan pelanggan hingga terciptanya sebuah loyalitas di dalamnya. Perusahaan-perusahaan besar biasanya membedakan divisi penjualan dan pemasaran meskipun aktivitas mereka erat berhubungan satu sama lain. Namun, pada skala UMKM, dua aktivitas ini harus dilakukan sendiri oleh penjual karena keterbatasan, salah satunya pada modal dan sumber daya manusia. Meskipun begitu, penjual harus tetap membedakan aktivitas penjualan dan pemasaran yang mereka lakukan. Sayangnya, sebagian besar peserta yang hadir pada acara pelatihan masih menjalankan peran penjualan saja belum sampai ke aktivitas pemasaran. Bahkan, banyak dari mereka yang belum memiliki nama atau merek produk sehingga akan sulit bagi pelanggan untuk melakukan identifikasi produk. 


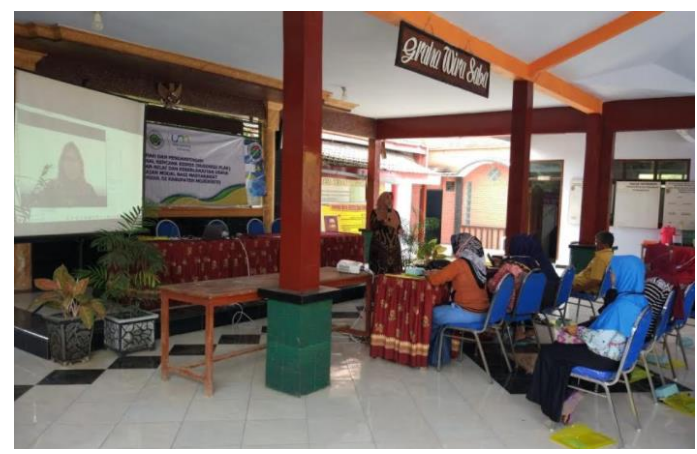

Gambar 4. Pemaparan Materi Pelatihan

Sumber: Dokumentasi Pribadi, 2020

Sebelum ke pelatihan pembuatan desain kemasan kekinian, peserta diajak untuk mengikuti sebuah kuis berhadiah. Tim pengabdian menyiapkan tiga barang yang telah dibeli di salah satu ritel modern di Kota Malang. Barang tersebut yaitu telur kampung, sawi gajah, dan juga tomat ceri. Ketiga produk dikemas dengan bagus. Tiga orang diminta untuk maju ke depan dan menebak harga dari tiap-tiap produk. Baik relawan kuis maupun peserta terkejut dengan harga dari ketiga barang tersebut. Harga dari barang tersebut bisa dua hingga kali lipat dari harga barang serupa di pasaran. Selain sebagai hiburan dan ice breaking, kuis ini dilakukan untuk membuka wawasan para peserta jika faktanya barang dengan kemasan yang bagus bisa dihargai ekstra lebih mahal dibandingkan harga serupa di pasaran.

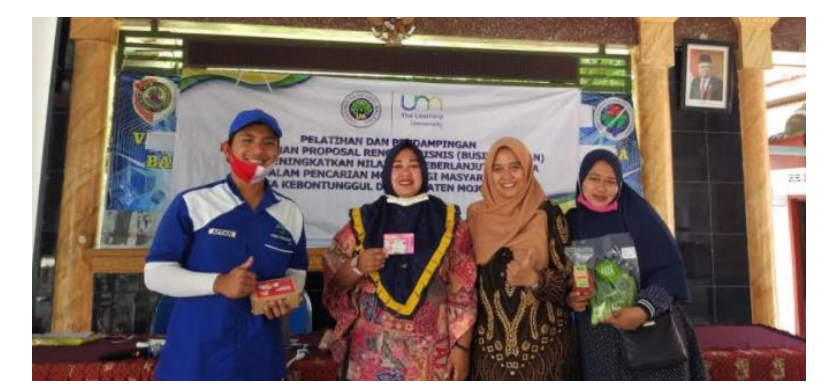

Gambar 4. Peserta Mengikuti Kuis Tebak Harga

Sumber: Dokumentasi Pribadi, 2020

Selanjutnya, tim pengabdian memaparkan cara-cara mendesain kemasan dengan mudah dan murah. Pertama, tim menjelaskan cara mendapatkan kemasan dengan harga murah. Tim menyarankan agar para peserta membeli kemasan melalui daring karena harga bisa selisih 500-2.000 rupiah rata-rata dengan harga di toko melalui pembelian 
secara fisik. Namun, ada peserta yang memiliki traumatis berbelanja melalui toko daring karena ketidak sesuaian antara produk di gambar dengan yang dikirim. Oleh sebab itu, tim juga memberikan beberapa tips mengenai cara-cara berbelanja daring agar mendapatkan produk dengan harga murah, berkualitas serta sesuai dengan keinginan pembeli. Beberapa tips tersebut diantaranya:

1. Mencari tahu nama kemasan terlebih dahulu. Salah satu contoh kemasan kekinian adalah standing pouch. Kemasan ini cocok digunakan untuk produk seperti jamu dan tortilla. Kemudian, nama tersebut diketikkan pada kolom pencarian di dalam situs belanja daring

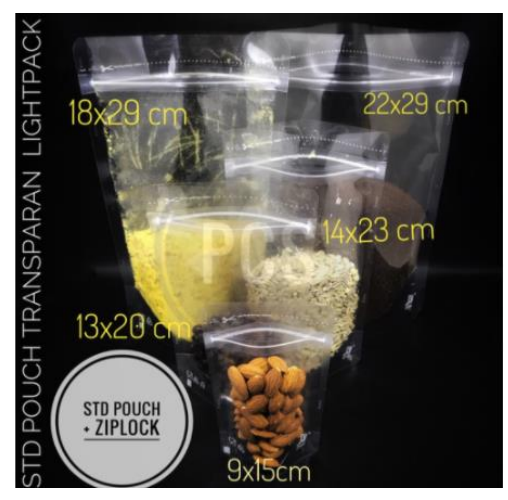

Gambar 5. Contoh Kemasan Kekinian

Sumber: shopee.co.id

2. Setelah itu, peserta menggunakan kolom filter dan memilih penjual yang berasal dari Jawa Timur. Hal ini dilakukan agar ongkos kirim tidak terlalu mahal bahkan bisa gratis jika sedang ada promosi dari situs belanja daring

3. Peserta memilih penjual dengan reputasi tinggi kemudian mengklik produk yang diinginkan. Sebelum melakukan pembelian, peserta bisa melihat deskripsi produk agar tidak salah dalam melakukan pembelian serta mengamati ulasan yang telah diberikan oleh pembeli lainnya

Tahap selanjutnya adalah membuat desain logo menggunakan canva, media power point, dan juga pencarian gambar melalui google. Langkah-langkah dalam pembuatan desain logo dipaparkan sebagai berikut:

1. Peserta membuka aplikasi canva melalui canva.com. Peserta disarankan melakukan registrasi agar logo yang dibuat tidak hilang. Setelah itu, peserta memilih desain yang diinginkan. Agar lebih mudah, peserta bisa langsung menuju fitur template, kemudian 
klik bisnis, lalu memilih logo. Peserta bisa memilih logo yang ditawarkan secara gratis dan melakukan modifikasi sesuai dengan bisnis yang dijalankan

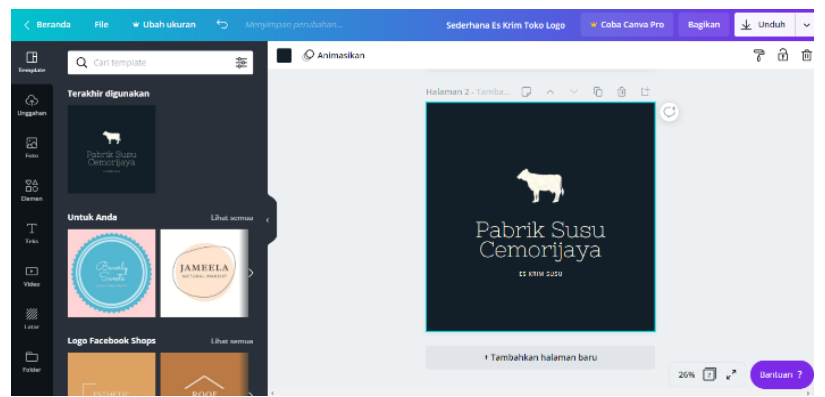

Gambar 6. Contoh Logo yang Dipilih pada Aplikasi Canva

2. Langkah selanjutnya, peserta mencari gambar sesuai dengan produk yang dihasilkan atau dijual, misalnya produk jamur. Peserta mencari gambar melalui google image. Tim pengabdian memberikan tips untuk menambahkan kata clipart dan menggunakan istilah jamur dalam Bahasa inggris, sehingga yang diketikkan pada kolom pencarian adalah mushroom clipart. Dengan menambahkan kata clipart, maka hasil pencarian gambar akan menunjukkan gambar-gambar jamur dengan tampilan visual yang lebih menarik

3. Setelah memilih gambar yang diinginkan, gambar tersebut disimpan. Peserta mungkin akan mendapatkan gambar dengan latar belakang putih dan tampilan tersebut akan mengganggu desain logo yang akan dibuat. Dalam menangani hal ini, peserta dapat mengedit gambar dengan mudah menggunakan media power point (ppt). Setelah membuka ppt, peserta melakukan salin tempel gambar yang sudah disimpan ke dalam ppt. Kemudian, gambar diklik hingga muncul fitur format pada menu paling atas. Setelah itu, peserta mengklik color kemudian set transparent color. Peserta juga bisa menyesuaikan warna jamur dengan logo yang sudah dipilih di canva. Gambar 8 menunjukkan tampilan gambar jamur setelah diedit. Setelah itu, peserta menyimpan Kembali gambar yang telah dimodifikasi ke dalam folder di dalam laptop atau computer dan Kembali ke aplikasi canva.

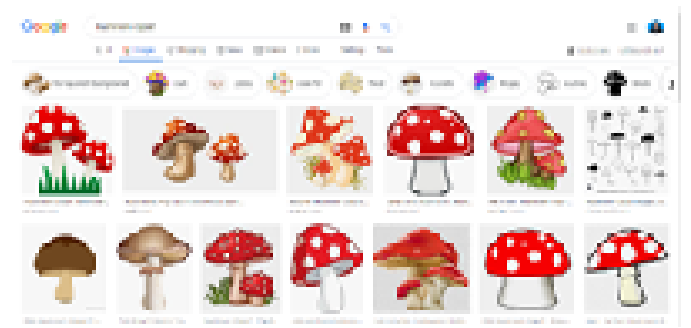

Gambar 7. Tampilan Hasil Pencarian Gambar Jamur di Google 
4. Pada aplikasi canva, peserta mengunggah gambar jamur yang telah diedit ke dalam aplikasi pada fitur unggahan di sebelah kiri. Setelah terunggah, gambar diklik sehingga gambar yang diinginkan akan muncul pada logo yang telah dipilih. Peserta selanjutnya bisa memodifikasi kata-kata atau menambahkan informasi, misalnya tanggal kaduluarsa dan lain sebagainya. Gambar 9 menunjukkan tampilan desain logo yang siap dicetak langsung pada kemasan. Jika biaya cetak kemasan terlalu mahal, peserta dapat mencetak logo pada kertas atau sticker kemudian menempelkannya pada kemasan.
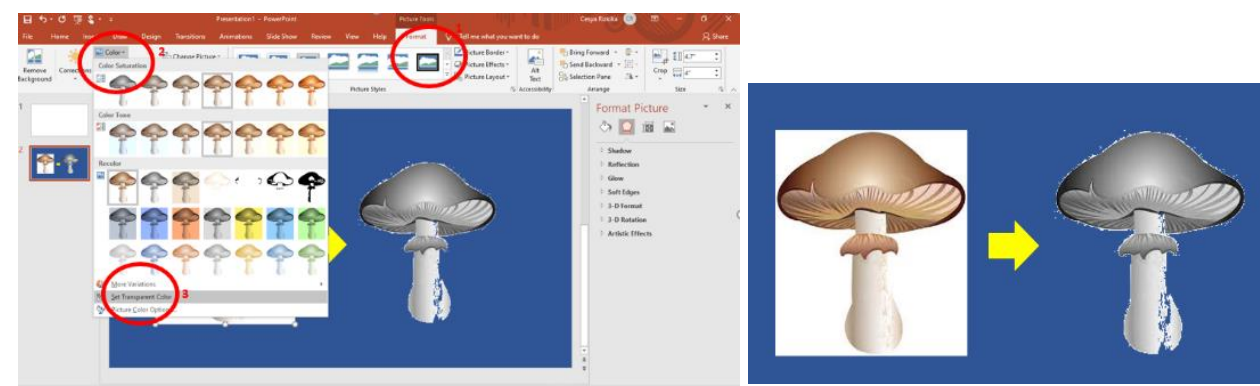

Gambar 8. Proses Edit Gambar pada Power Point

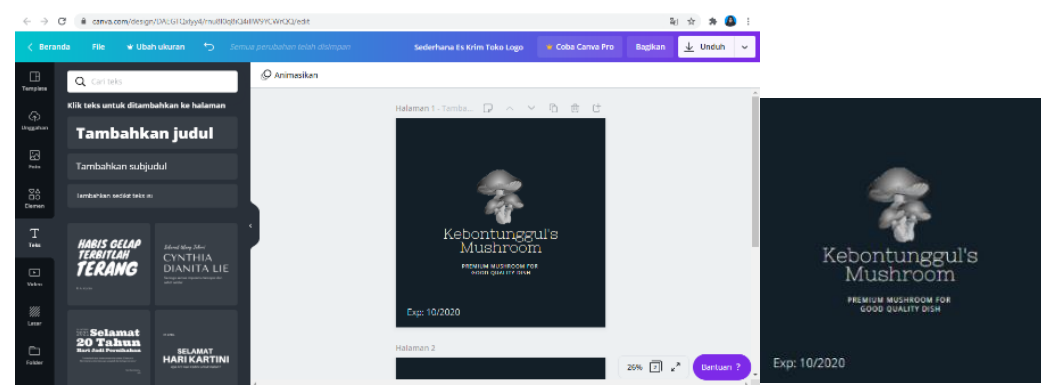

Gambar 9. Hasil Desain Logo Siap Cetak

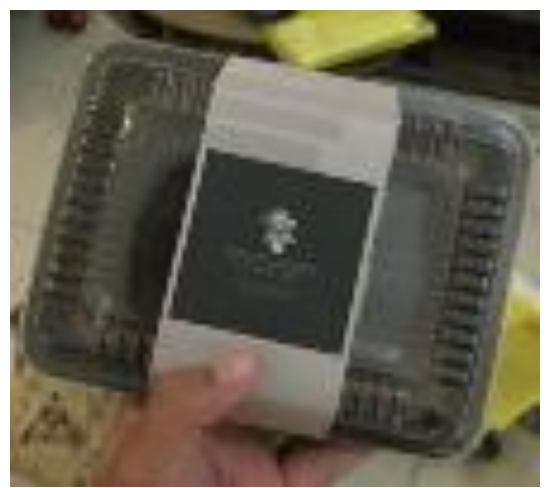

Gambar 10. Contoh Logo Dicetak dan Ditempel pada Kemasan Kekinian 
Pelatihan ditutup dengan sesi tanya jawab dari peserta. Pertanyaan pun beragam mulai dari menanyakan kualitas pembelian kemasan melalui toko daring hingga proses pembuatan kemasan melalui canva. Setelah pelatihan, tim mengadakan proses pendampingan melalui daring untuk meminimalisir aktivitas kontak fisik di tengah kondisi pandemi covid-19. Proses pendampingan ini dibantu oleh perangkat BUMDES.

\section{SIMPULAN}

Salah satu jenis pelatihan yang dapat diberikan guna melakukan pemberdayaan masyarakat desa adalah mengenai rencana bisnis. Rencana bisnis (business plan) merupakan salah satu dokumen penting bagi seorang wirausaha ketika akan meluncurkan bisnisnya. Setelah melakukan kegiatan observasi dan diskusi dengan para perangkat desa, tim pengabdian FE UM diminta memberikan pelatihan mengenai proposal rencana bisnis khususnya pada rencana pemasaran mengenai desain logo serta kemasan kekinian.

Ada berbagai manfaat yang akan didapatkan oleh pelaku usaha, tidak terkecuali UMKM, ketika melakukan perbaikan pada kemasan salah satunya meningkatnya harga jual dari suatu produk. Dengan adanya pelatihan ini, diharapkan para pelaku usaha di Desa Kebontunggul dapat mulai melakukan perbaikan pada kemasan yang mereka gunakan selama ini dengan mengikuti tren kekinian. Teknologi yang ada saat ini memungkinkan para pelaku UMKM membuat desain logo serta kemasan dengan mudah dan murah. Produk dengan desain logo serta kemasan kekinian diharapkan mampu bersaing di pasaran terlebih dengan rencana pembentukan BUMDES mart di Desa Kebontunggul sebagai wadah bagi masyarakat dalam menjual produk-produk yang mereka olah dan hasilkan.

\section{UCAPAN TERIMA KASIH}

Tim pengabdian masyarakat FE UM mengucapkan terima kasih kepada semua pihak yang telah membantu dan terlibat pada kegiatan pengabdian masyarakat yang telah berlangsung di Desa Kebontunggul, Kabupaten Mojokerto. Ucapan terima kasih khususnya diberikan kepada Dinas Pemberdayaan Masyarakat Desa (PMD) Kabupaten Mojokerto, perangkat desa Kebontunggul, serta pengurus BUMDES Kebontunggul atas kesempatan yang telah diberikan. 
Parahiyanti, Penguatan Strategi Pemasaran....153

\section{DAFTAR RUJUKAN}

Hisrich, R. D., Peters, M. P., Shepherd, D. A. (2017). Entrepreneurship (10 th ed). New York: Mc-Graw Hill

Lin, D. (2017). The Power of Packaging You Probably Did Not Know About. Diakses melalui https://www.packagingoftheworld.com/2017/07/the-power-of-packaging-youprobablydid.html\#: :text=Packaging\%20is\%20at\%20the\%20heart,of\%20an\%2 0effective\%20packaging\%20is.

Yasin, N. (2019). Pemberdayaan Masyarakat dalam Pembangunan Desa. Diakses melalui https://dpmd.jatimprov.go.id/component/content/article/90-berita/492-opinipemberdayaan-masyarakat-dalam-pembangunan-desa. 
154 J-Abdipamas, Vol. 4, No. 2, Oktober 2020 